\title{
ON A SUPERFICIAL DEPOSIT AT ST. ANDREW'S, GUERNSEY.
}

(i.) A Description of the Section.

By B. G. CHILCOTT, F.G.S., and L. RICHARDSON, F.R.S.E., F.G.S.

(2.) Petrology of Samples of Brickearth, etc., from THE Locality.

By P. G. H. BOSWELL, O.B.E., D.Sc., F.G.S.

(Read May 6th, 1921.)

\section{PART I.}

NEAR the Brick Works at St. Andrew's is a pit from which is obtained the brickearth that is used for the manufacture of the bricks. It is situated some 300 yards east-by-south of St. Andrew's Church, and is described as a "Sand Pit" on the 25 inch map, Sheet iv., 6 (Ist ed. I900), Guernsey. The section is as follows:-

Brickearth : about.............. 7 ft. 6 ins.

Decomposed gneiss : seen about ..... I7 ft.

The base of the brickearth-or the top of the decomposed gneiss-is about 240 feet above the assumed level of the sea at St. Peter Port. Both brickearth and decomposed gneiss are used for brickmaking. On the occasion of our first visit to the pit in August 1920, the brickearth was some feet thicker than when one of us (B. G. C.) visited it a second time in December 1920. Appearances suggest that it had been preserved in a hollow-probably the head of a valley-in the gneiss.

As a rule the brickearth is unstratified, but on the occasion of the first visit a portion was observed to be imperfectly laminated and contorted. It was examined very carefully to see if it contained any pebbles, but it did not, with the exception of a very few angular fragments of a fine-grained sandy rock which might easily have escaped detection.

The only notice of the deposit at this locality - so far as we are aware -is contained in Mr. Collenette's paper on "The Pleistocene Period in Guernsey," in which he states that "clay" -regarded by him as Glacial-is worked at St. Andrew's." and he informed us that he considered it to be his "Upper Glacial Clay."

It appeared desirable to us to describe the section in order to draw attention to it and also to have a thorough investigation made of the rocks exposed, with a view to ascertaining if any light could thereby be thrown on the source of the constituents of the brickearth and the conditions under which they had been accumulated. Hence the origin of the present communication

- Trans. and Repont Guernsey Soc. Nat. Hist., 1916 (1917), p. 375. 
and the interesting contribution on the petrology of the rocks by Prof. Boswell.

When one of us described the brickearth to Mr. E. E. L. Dixon, he said that it appeared to be very similar to that which Mr. George Barrow had found in the Scilly Isles, where it was known as the "Iron-cement Bed," the stoneless phase of which was comparable with the "Limon" on the Brittany Coast."We accordingly submitted a sample to Mr. Barrow, together with a brief account of the section. He favoured us with the following remarks (in litt.) :-

"I am interested in the brickear th you sent. It is like the Scilly-Isles deposit, but more like the 'Limon' on the coast of Brittany. The reason is that the Scilly-Isles deposit is low down and a powerful gale will drive small stones into it from the adjacent beach. The French 'Limon' that I saw is much higher up; little stones from the shore would be rarely lifted so high and the "Limon" is much more stoneless than the Scilly-Isles deposits and a cemented deposit. I should be surprised if you did not find an equivalent to the French coastal 'Limon' on the Channel Islands in suitable spots. The thin flaky stone you sent would travel hundreds of feet in a gale. I have known burnt alum-shale flakes lifted a great height above seashore on the Yorkshire coast, and of course their shape and lightness help in lifting such bits of stone. The French 'Limon' is curious in retaining a nearly vertical face; long after it has been cut open it will remain nearly vertical to a depth of some ten feet in railway-cuttings. The depth to which the gneiss is decomposed is interesting : the ScillyIsles granite is rarely quite decomposed. As a rule the immediately underlying granite in the Scilly Isles occurs in lenticular masses: there is a moderately defined edge to each lenticle, the cores are fairly hard, but the material around is loose and quite decomposed. The same is true of the granites in the mainland (Cornwall)."

From the facts and observations recorded in the two parts of this communication it is evident that a portion of the brickearth is composed of matter derived from the gneiss of the neighbourhood, and it is probable that some of the constituents have been blown here from a distance --Prof. Boswell suggests from land possibly now removed by erosion. In answer to a direct question as to whether any of the constituents exhibited evidence of wind action, Prof. Boswell replied:-

"No, there was nothing about it that I could say was definite evidence of wind transport-no rounded or etched grains, etc. But the fine material might well be wind-

\footnotetext{
" "The Geology of the Isles of Srilly," Mem. Geol. Surv. (1906), pp. Iq-21, and $27 \& 28$.
} 
transported. The loess, for example, contains angular grains of minerals, and microscopically shows little evidence of wind action."

\section{PART II.}

The brickearth is brown and loamy in general character and contains abundant fragments of decomposed gneiss, similar to the decomposed gneiss immediately below.

Its mechanical composition is peculiar. Elutriation of the sample gave the following results:-

Very coarse sand, $2 \mathrm{~mm}$. to I mm., $6.2 \%$; coarse sand, $\mathrm{Imm}$, to $0.5,3.2 \%$; medium sand, 0.5 to $0.25, \mathrm{I} .8 \%$; fine sand, 0.25 to $0.1,49 . \mathrm{I} \%$; coarse silt, 0.1 to 0.05 , 3.I\%; fine silt 0.05 . to $0.01,27.3 \%$; clay, less than o.or mm. diameter, $9: 3 \%$. These results when plotted do not yield an even curve. The relatively large proportion of fine silt is anomalous. Altogether the results of analysis suggest an admixture of residual material produced by the decomposition of the gneiss in situ, with water or windborne fine sandy, silty, and clayey sediment.

The fresh gneiss of the neighbourhood, as seen in a thin slice of a specimen obtained from the quarry south of the Brick Works, is coarse-grained, and consists of augen of felspar surrounded by dark hornblende and biotite, so that a general banded character is given to the rock. Besides the green hornblende and brown biotite, some quartz occurs. Apatite and black iron ores are plentiful. The felspar is finely striated and lamellartwinned, and from its extinction angle and refractive index probably approaches oligoclase in composition.

The brickearth was treated with bromoform, and the detrital minerals of density greater than 2.83 were examined. An abundant residue was obtained, consisting largely of common hornblende in ragged and angular grains. The average size was $0.4 \times 0.2 \mathrm{~mm}$. The mineral showed the usual pleochroism, parallel to $\mathrm{Z}$ dark bluish green, and parallel to $\mathrm{Y}$ and $\mathrm{X}$ pale green. Cleavage flakes of brown biotite and clear muscovite, of diameter $0.2 \mathrm{~mm}$., were also plentiful. The average size of the other minerals was, except for colourless garnets, $0.2 \mathrm{~mm}$. across, so much less as to suggest in part a different origin ; their diameter rarely exceeded $0.08 \mathrm{~mm}$., and averaged $0.05 \mathrm{~mm}$. Very little magnetite was present, but ilmenite was abundant. Tourmaline in brownish-grey and chocolate-coloured crystals, rounded prisms of apatite (the rounding being due probably to solution), foxy-red and yellow rutile, and well-shaped zircon, all of diameter 0.04 to 0.06 , were plentiful. Epidote in pistachiogreen to colourless angular fragments was very abundant, and chlorite also was found.

In addition, grains of kyanite (.08 mm. long), abundant staurolite (not in ragged grains) and several grains of glauco- 
phane were observed. The glaucophane showed prismatic form, in one case terminated by domes, and displayed the wellknown pleochroism, parallel to $Z$ royal blue, parallel to $Y$ violet, In optical characters it more closely resembled the glaucophane in the rocks of the 1 . de Groix, Brittany, than the Anglesey material. The mineral occurs only rarely in British sediments.

Many of the minerals listed above may well have been derived from the rocks occurring in Guernsey. Such are the abundant unrolled hornblende and biotite, the solution-rounded apatite, the zircon, epidote, chlorite and possibly some of the rutile.* But nowhere in Guernsey have I seen, nor do I know of any records of rocks bearing kyanite, staurolite and glaucophane. On the other hand, these minerals occur abundantly in the rocks of Brittany and may have been derived from that district or parts of the old "Armorica" now submerged. The grains display a certain loss of angularity by ercsion.

In some respects the brickearth resembles the French and Belgian "limon," but on the whole, it is coarser. Some admixture of "limon"-material may, however, occur in it.

\section{VISIT TO THE GEOLOGICAI DEPARTMENT, KING'S COLLEGE (UNIVERSITY OF LONDON). \\ SATURDAY, JANUARY 29TH, I92I. \\ Report by I. Dudley Stamp, D.Sc., F.G.S.}

A SERIFs of exhibits was arranged to illustrate the teaching work of the Department and the research work of the staff and senior students. Particular interest was aroused by Prof. Gordon's collection of gemstones and by the demonstration in the making of a rock section. With the very simple cutting and grinding apparatus in the Department a slide can be completed in less than half-an-hour, and several were made for the inspection of the visitors. The President, on behalf of the party of sixty visitors, cordially thanked Professor W. T. Gordon for his demonstration and for the pleasant tea, and also his assistants, Mr. A. K. Wells and Dr. L. D. Stamp for their part in the afternoon's programme, and last but not least, the students of the Department, Miss A. G. R. Stratford and Miss E. C. Rea for their assistance at the tea-table. 